\title{
PENGEMBANGAN VIDEO ANIMASI BERBASIS KARAKTER CINTA TANAH AIR UNTUK ANAK USIA DINI
}

\author{
Dian Miranda \\ Dosen Prodi PG PAUD FKIP Untan \\ Dian.miranda@fkip.untan.ac.id
}

\begin{abstract}
Abstrak
The aim of this study is to develop animated characters based on love of homeland for early childhood. The research method used in this study is $R \& D$ research. The development model in this study refers to the $4 D$ research and development model (four-D). According to Thiagarajan (1974) the 4D research and development model consists of 4 main stages, namely define, design, develop, and disseminate. The data analysis technique used in this study is a mixed analysis technique that is a combination of qualitative analysis and quantitative analysis. The results of video validation carried out by 4 validators were an average of 2.8 with a maximum score of 3 , included in the very feasible category used as learning media to develop the character of love for the homeland in early childhood.
\end{abstract}

Kata Kunci: animated video, the character of love for the homeland

\section{PENDAHULUAN}

Pendidikan karakter merupakan bentuk pendidikan yang wajib dikenalkan dan ditanamkan kepada anak-anak sejak dini. Pendidikan ini mengajarkan kepada anak untuk berbuat dan membiasakan diri berbuat kebaikan.

Pendidikan karakter menjadi penting ditanamkan pada semua orang, karena akan sangat bermanfaat bagi kehidupannya baik kehidupan pribadi, sosial, bernegara, dan kehidupan beragama. Mahatma Gandhi pernah mengemukakan setinggi apapun pengetahuan manusia tidak bermakna tanpa moralitas dan karakter mulia.

Salah satu karakter yang diamanatkan oleh Kementerian Pendidikan Nasional
Terkait dalam hal berkehidupan bernegara ialah karakter cinta tanah air dan semangat kebangsaan. Belakangan semangat kebangsaan terasa semakin menipis, baik di kalangan orang dewasa, remaja, bahkan anak-anak. Dengan derasnya arus globalisasi saat ini, tanpa terasa telah menyebabkan terkikisnya nilai-nilai kebangsaan.

Salah satu cara pembentukan karakter ialah melalui bercerita, barcerita dapat dilakukan dengan berbagai cara, baik secara langsung maupun menggunakan media penyalur seperti tv, video, youtube, dan sebagainya. Hal ini dibuktikan oleh salah satu penelitian tentang kekerasan dalam media di Amerika Serikat oleh 
American Psychological Association pada tahun 1995, ada tiga kesimpulan menarik. Pertama, mempresentasikan program kekerasan meningkatkan perilaku agresif. Kedua, memperlihatkan secara berulang tayangan kekerasan dapat menyebabkan ketidakpekaan terhadap kekerasan dan penderitaan korban. Ketiga, tayangan kekerasan dapat meningkatkan rasa takut sehingga akan menciptakan representasi dalam diri penonton, betapa berbahayanya dunia (Jehel, 2003).

Video dalam pendidikan anak usia dini memiliki pengaruh besar terhadap perkembangan anak, hal ini terbukti dari penelitian mengenai pengaruh video terhadap perkembangan anak, salah satunya penelitian yang dilakukan oleh mira (2014) yang menemukan bahwa terdapat pengaruh yang signifikan pengaruh penggunaan video dalam pembelajaran terhadap perkembangan kognitif anak. Selain itu penelitian lain yang dilakukan oleh Kusumadana (2016) membuktikan bahwa penggunaan video "Diva the Series" meningkatkan kecerdasan emosional anak. Penelitian seblumnya yang dilakukan oleh Lestarinigrum (2014) menunjukkan hasil bahwa pembelajaran mengembangkan nilai-nilai moral agama dengan menggunakan media VCD (Fiqih Anak dan Upin Ipin) mampu meningkatkan penanaman nilai-nilai moral agama secara signifikan. Dari beberapa hasil penelitian di atas dapat disimpulkan betapa besar dampak konsumsi video terhadap berbagai aspek perkembangan anak. Oleh sebab itu kita perlu membuat atau mengembangkan video yang bersifat mendidik dan dibuat oleh bangsa kita sendiri disesuaikan dengan kebutahan pendidikan, yang dalam penelitian ini disesuaikan untuk mengembangkan karakter nilai cinta tanah air.

Menurut Yuliatin (dalam Erni, 2016), cinta tanah air adalah rasa bangga, rasa menghargai, rasa memiliki, rasa menghormati dan loyal pada negara tempat ia tinggal, hal ini tergambar dari perilakunya menjaga dan melindungi negaranya, rela berkorban demi kepentingan bangsa, serta turut melestarikan budaya-budaya yang ada di negara tersebut. Cinta tanah air adalah berupaya dengan sepenuh hati menerima tanah tumpah darah/negara kita sebagai bagian yang harus kita lindungi dan kita kembangkan (Rusyan, 2013). Rasa cinta tanah air dapat dipahami sebagai suatu perasaan mencintai bangsa dengan sepenuh hati sehingga berusaha untuk melindungi dan memajukan kehidupan bangsanya agar dapat bersaing dengan bangsa lain.

Rasa cinta tanah air harus ditanamkan kepada anak sejak dini agar sebagai generasi penerus bangsa dapat mewujudkan sikap dan tingkah laku yang bermanfaat bagi kepentingan masyarakat dan menghindari penyimpanganpenyimpangan sosial yang dapat merusak norma-norma dan nilai-nilai kebudayaan Indonesia. Karena nilai-nilai kebudayaan bangsa mencerminkan kecintaan kita terhadap bangsa dan negara.

Sikap nasionalisme atau identitas bersama di bentuk oleh beberapa factor yang menurut Ramlan Surbakti (1999:4447) faktor tersebut adalah: (1) Primordial, yaitu ikatan kekerabatan dan kesamaan suku bangsa, daerah, bahasa, dan adat istiadat untuk membentuk suatu negara atau bangsa. (2) Sakral, yakni kesamaan agama yang dipeluk oleh suatu masyarakat; (3) Tokoh, kepemimpinan dalam suatu komunitas dapat menjadi salah satu faktor 
yang membentuk suatu negara atau bangsa; (4) Sejarah; (5) Bhinneka Tunggal Ika, prinsip bersatu dalam perbedaan; (6) Perkembangan Ekonomi, Perkembangan ekonomi (industrialisasi);

Kelembagaan.

Bangsa Indonesia adalah bangsa yang terdiri berbagai macam suku, budaya, agama, dan Bahasa yang apabila tidak dirangkul dengan benar akan berpotensi besar menimbulkan perpecahan. Oleh sebab itu salah satu upaya yang dapat dilakukan ialah dengan memberikan pemahaman kepada anak dari sejak dini, walau kita berbeda baik dari suku, agama, budaya, Bahasa, dan sebagainya kita adalah bagian dari bangsa Indonesia yang satu, kita berkewajiban menjaga kedaulatan Indonesia dengan menjaga hidup rukun bendampingan dan saling menghargai satu sama lain dalam berkehidupan bermasyarakat terutama ketika berteman harus saling menyayangi, menghargai, dan menjaga perdaiman. Salah satunya ialah dengan mengenalkan berbagaimacam suku dan agama yang ada disekitar lingkungan anak, sehingga mereka akan merasa akrab dengan perbedaan tersebut dan dapat hidup rukun dengan sesama walau berbeda suku, agama, maupun budaya.

Pada anak usia dini, yang dapat dilakukan guru untuk membangun sikap toleransi antar umat beragama ialah (1) mengenalkan beberapa agama yang dianut di Indonesia, cara menghargai dan bersikap terhadap sesama umat beragama; (2) memperkenalkan tempat-tempat ibadah, agar anak-anak sadar tumbuh dalam negara yang memiliki keragaman khususnya agama; (3) memperkenalkan jenis-jenis hari besar setiap agama di Indonesia; (4) saling mendatangi tempat ibadah; (5) memantapkan pemahaman dan strategi belajar untuk menyatukan persepsi dan kebulatan tekad dalam menjaga kerukunan antara umat beragama (Zaini, 2010).

Untuk menanamkan sikap cinta tanah air pada anak TK dapat di lakukan melalui berbagai kegiatan. Atika (2014) dalam penelitiannya menjelaskan bahwa pelaksanaan pendidikan karakter cinta tanah air bisa dilakukan sebelum masuk kelas, proses pembelajaran, pulang sekolah, dan ekstrakurikuler yang diadakan di sekolah. Lickona (1991) menyarankan agar pendidikan karakter berlangsung efektif maka guru dapat mengusahakan implementasi berbagai metode seperti bercerita tentang berbagai kisah, cerita atau dogeng yang sesuai, menugasi anak membaca literatur, melaksanakan studi kasus, bermain peran, diskusi, debat tentang moral dan juga penerapan pembelajaran kooperatif.

Salah satu metode pendidikan karakter ialah dengan bercerita, dimana bercerita adalah menuturkan sesuatu yang mengisahkan tentang perbuatan atau suatu kejadian dan disampaikan secara lisan dengan tujuan membagikan pengalaman dan pengetahuan kepada orang lain (Bachir, 2005). Bercerita dapat dilakukan secara langsung maupun menggunakan media. Bercerita secara langsung ialah si pencerita dan yang mendengar cerita bertatap muka secara langsung, sedangkan bercerita secara tak langsung sipencerita tidak bertatap muka secara langsung dengan pendengar cerita, melainkan mbercerita menggun akan alat bantu baik berupa alat bantu audio, missal nya radio, telpon, rekaman suara, dan sebagainya, maupun audio visual yang berupa rekaman video, film dan sebagainya.

Video adalah salah satu media audio visual yang digunakan sebagai media 
komunikasi untuk menjelaskan atau menyampaikan pesan, serta digunakan sebagai hiburan. Video merupakan gambargambar dalam frame, di mana frame demi frame diproyeksikan melalui lensa proyektor secara mekanis sehingga pada layar terlihat gambar hidup (Arsyad, 2011). Dalam kamus besar bahasa Indonesia (1988) video adalah bagian yang memancarkan gambar pada dimensi pesawat televisi atau rekaman gambar hidup atau program televisi untuk ditayangkan lewat pesawat televisi maupun komputer. Maka dari paparan di atas dapat dijelaskan Secara sederhana bahwa video merupakan tayangan gambar bergerak yang disertai dengan suara.

Kelebihan media video ialah dapat menyajikan informasi, memaparkan proses, menjelaskan konsep-konsep yang rumit, mengajarkan keterampilan, menyingkat atau memperpanjang waktu, dan mempengaruhi sikap. Menurut Ronal Anderson (1987) video dapat digunakan dengan tujuan mempengaruhi sikap dan emosi. Selain itu Daryanto (2010) juga mengemukakkan bahwa video merupakan suatu medium yang sangat efektif untuk membantu proses pembelajaran, baik untuk pembelajaran masal, individual maupun berkelompok. Oleh sebab itu media video dapat memberikan pengaruh terhadap perkembangan karakter anak.

Ada terdapat banyak macam video, salah satunya ialah video animasi. Anismasi biasa dikenal dengan istilah motion picture yang mempunyai pengertian gambar bergerak. Disebut gambar bergerak karena dalam proses pembuatannya di gunakan gambar yang berurutan dan dimanipulasi sedemikian rupa sehingga tampak seolah-olah gambar tersebut dapat bergerak. Menurut Munir (2012) visual animasi adalah proses penciptaan efek gerak atau efek perubahan bentuk yang terjadi selama beberapa waktu. Fernandez (2002) juga mengemukan bahwa Animasi adalah sebuah proses merekam dan memainkan kembali serangkaian gambar statis untuk mendapatkan sebuah ilusi pergerakan. Dengan kata lain dapat disimpulkan video animasi ialah sebuah media audio visual yang terdiri dari gabungan antara gambar dan suara, dimana video ini dibentuk oleh sekumpulan gambar yang diatur sedemikina rupa segingga dapat menimbulkan ilusi gerak atau gambar yang bergerak.

\section{METODE}

Metode penelitian yang digunakan dalam penelitian ini ialah metode Metode penelitian $\mathrm{R} \& \mathrm{D}$. metode ini digunakan untuk menghasilkan produk tertentu, dan menguji keefektifan produk tersebut. Model pengembangan dalam penelitian ini mengacu pada model penelitian dan pengembangan 4D (four-D). Menurut Thiagarajan (1974: 5) model penelitian dan pengembangan 4D terdisi atas 4 tahap utama, yaitu define, design, develop, dan disseminate. Menurut Triyanto (2010: 189), model pengembangan 4D dapat diadaptasikan menjadi 4P yaitu: pendefinisian, perancangan, pengembangan, dan penyebaran.

Subjek penelitian (sumber data primer) dalam penelitian ini adalah anak usia 3-5 tahun yang ada di lembaga PAUD Al-Kausar Pontianak untuk mengetahui keefektifan video animasi yang dikembangkan berupa respon yang diberikan anak serta pengetahuan dan sikap cinta tanah air yang akan dikembangkan melalui teknik pengumpulan data observasi dan wawancara. Selain anak, sumber data 
DOI: $\underline{10.26418 / \text { jvip.v11i2.32565 }}$

dalam penelitian ini juga melibatkan guru TK di Pontianak untuk mendapatkan data kelayakan media video animasi dari
Vol 11, No 2 (2019)-Dian Miranda segi materi dan media untuk mencapai tujuan pembuatan video dengan teknik pengumpul datanya berupa angket.

Tabel 1. Alur Pengembangan yang dilakukan dalam Penelitian

\begin{tabular}{|c|c|c|}
\hline TAHAP & KEGIATAN & DETAIL \\
\hline \multirow[t]{5}{*}{ I } & \multirow[t]{5}{*}{ Pendefinisian } & $\begin{array}{l}\text { Menentuka tujuan : mengembangkan karakter cinta } \\
\text { tanah air }\end{array}$ \\
\hline & & Mentukan karakteristik karakter cinta tanah air AUD \\
\hline & & Menentukan tema dalam kurikulum PAUD: negaraku \\
\hline & & $\begin{array}{l}\text { Menentukan materi : keunggulan kota pontianak } \\
\text { (makanan, budaya, tempat wisata, dll) }\end{array}$ \\
\hline & & Menentukan jenis video : video animasi interaktif \\
\hline \multirow[t]{6}{*}{ II } & \multirow[t]{6}{*}{ perancangan, } & Membuat story board \\
\hline & & Menentukan alur, tokoh, dan latar \\
\hline & & Membuat skenario \\
\hline & & Penyiapan materi \\
\hline & & Perangcangan gambar dan suara \\
\hline & & Penyatuan gambar dan suaraa (proses animasi) \\
\hline \multirow[t]{3}{*}{ III } & \multirow[t]{3}{*}{ pengembangan } & Validasi ahli (guru PAUD) \\
\hline & & Uji coba produk (kelas PAUD) \\
\hline & & revisi \\
\hline \multirow[t]{2}{*}{ IV } & \multirow[t]{2}{*}{ penyebaran } & Jurnal nasional (submit) \\
\hline & & Penyerahan VCD/file video ke TK Alkausar \\
\hline
\end{tabular}

\section{HASIL DAN PEMBAHASAN}

Hasil

Penelitian ini dilakukan melalui 4 tahap yang telah direncanakan, hasil dari pelaksanaan tiap tahap tersebut sebagai berikut:

1. Langkah pendefinisian

Langkah pertama dalam tahap pendefinisian adalah menentukan tujuan pengembangan yaitu pembuatan video edukatif yang dapat mengembangkan karakter cinta tanah air. Setelah menentukan tujuan maka peneliti harus menentukan fokus utama dalam pengembangan video ini dengan menemukan karakteristik karakter cinta tanah air pada anak usia dini, yaitu cara berfikir, bertindak, dan berbuat yang menunjukkan kesetiaan, kepedulian, dan penghargaan yang tinggi terhadap bahasa, lingkungan fisik, sosial, budaya, ekonomi, dan politik bangsa. Dalam hal ini anak dikembangkan kemampuan kepedulian dan penghargaannya terhadap lingkungan fisik dalam hal ini tempattempat ibadah yang ada di pontianak, yang layak dibanggakan, seperti masjid raya mujahidin pontianak, gereja katedral pontianak, vihara maitreya pontianak dan pura giri pati mulawarman.

2. Perancangan 
DOI: $\underline{10.26418 / \text { jvip.v11i2.32565 }}$

Pada langkah perancangan peneliti harus membuat story board dan skenario untuk menentukan gambar animasi yang ditampilkan dalam video. Seting tempat difokuskan pada empat tempat ibdah di pontianak yaitu masjid mujahidin, gereja katedral, vihara maitreya, dan pura giri pati mulawarman pontianak. Anak-anak TK mengadakan field trip bersama
Vol 11, No 2 (2019)- Dian Miranda

guru berkunjung melihat tempattempat ibadah tersebut dan mengagumi keindahan masing-masing tempat ibadah tersebut, skenario secara lengkap dilampirkan di lampiran.

Setelah skenario dan storyboard selesai maka tim animator membuat video animasi bersama peneliti, berikut hasil animasinya:
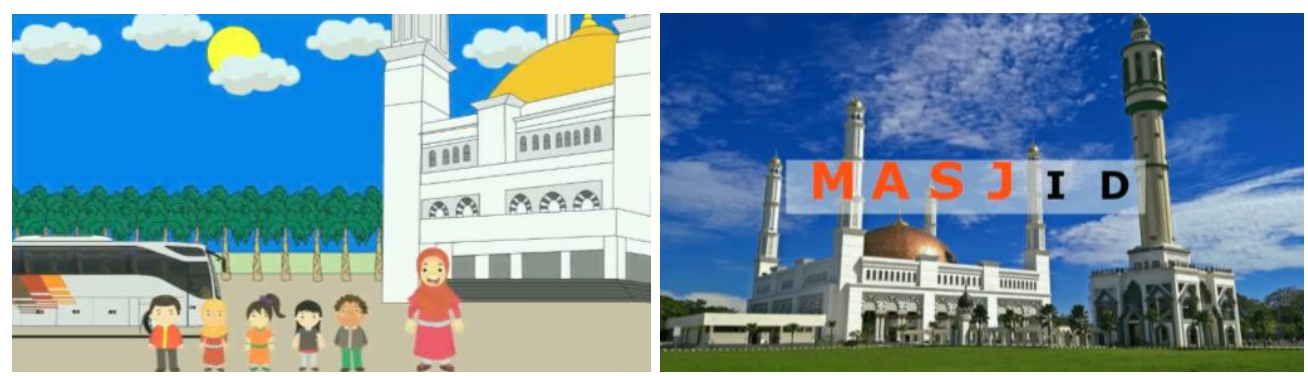

Gb. 4 Masjid mujahidin Pontianak

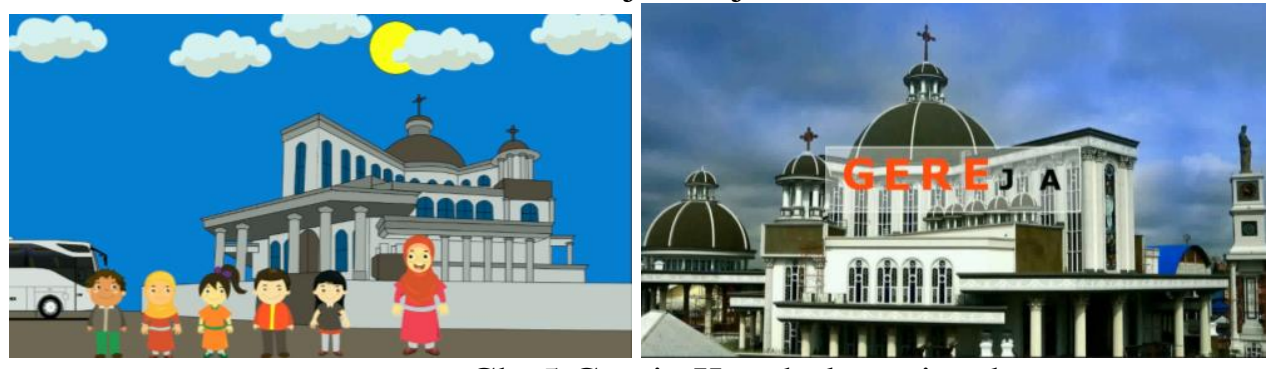

Gb. 5 Gereja Katedral pontianak

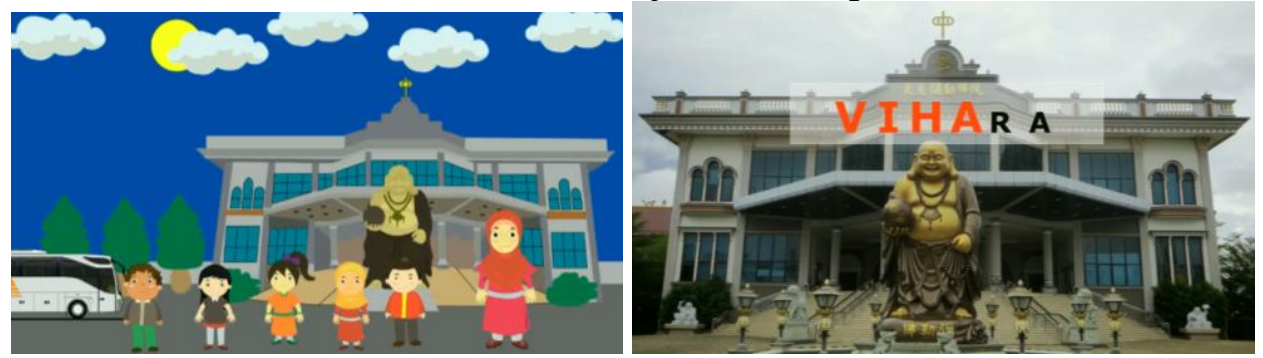

Gb. 6 Vihara maitreya pontianak 

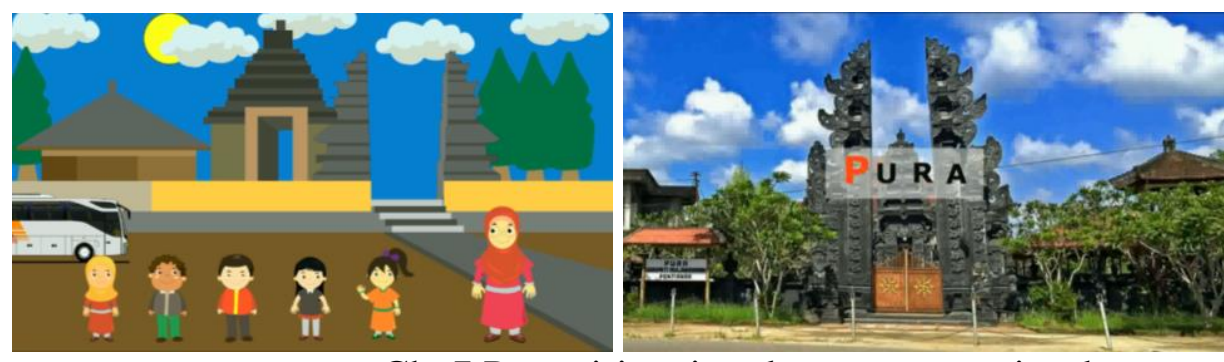

Gb. 7 Pura giri pati mulawarman pontianak

3. Pengembangan

Dalam tahap pengembangan terdapat tiga langkah yang dikaukan oleh peneliti yaitu:

1. hasil validasi media/video animasi uji validasi video dilakukan oleh guru TK dengan pertimbangan mereka lebih memahami karakteristik anak dan memahami kebutuhan media dalam pembelajaran, selain itu instrumen validasi telah disiapkan sesuai dengan karakteristik media yang sesuai untuk anak usia dini.

Tabel 2. Hasil Validasi

\begin{tabular}{lllllll}
\hline No & Komponen & Validator 1 & Validator 2 & Validator 3 & Validator 4 \\
\hline 1 & Kejelasan pesan & 2,7 & 3 & 2,7 & 3 & \\
\hline 2 & Berdiri sendiri & 2,5 & 2,5 & 3 & 2,5 & \\
\hline 3 & User friendly & 3 & 3 & 3 & 3 & \\
\hline 4 & Representasi isi & 2,7 & 3 & 2,7 & 3 & \\
\hline 5 & visualisasi & 2,8 & 2,8 & 3 & 2,5 & \\
\hline 6 & Kualitas gambar & 2,5 & 2,5 & 3 & 2,5 & \\
\hline 7 & pemanfaatan & 3 & 3 & 3 & 2,4 & 19,5 \\
\hline Jumlah & 19,2 & 19,8 & & 2,9 \\
\hline Rata-rata & 2,7 & 2,8 & & 2,8 \\
\hline Rata-rata semua validator
\end{tabular}

Skor maksimal $=3$, skor minimal 1

$$
\begin{aligned}
\mathrm{Mi} & =1 / 2 \times(1+3) \\
& =2 \\
\mathrm{Sbi} & =1 / 6 \times(3-1) \\
& =0,3
\end{aligned}
$$

Tabel 3. Kategorisasi Hasil Validasi dengan 4 Kriteria

\begin{tabular}{lcl}
\hline No & Rentang skor & \multicolumn{1}{c}{ Kategorisasi } \\
\hline 1 & $\mathrm{x}>2,45$ & Sangat layak \\
\hline 2 & $2<\mathrm{x}<2,45$ & Layak \\
\hline 3 & $1,15<\mathrm{x} 2$ & Krang layak \\
\hline 4 & $\mathrm{x}<1,15$ & Tidak layak \\
\hline
\end{tabular}


DOI: $\underline{10.26418 / \text { jvip.v11i2.32565 }}$

Jika melihat rata-rata hasil validasi maka dapat di simpulkan media video animasi interaktif yang dikembangkan oleh peneliti masuk dalam kategori sangat layak.

2. Hasil uji coba media.

Ujicoba media dilakukan pada 17 orang anak TK kelas B di TK alkausar, tujuan ujicoba pada anak dilakukan untuk melihat keefektifan video sebagai media belajar dan ketercapaian tujuan pembelajaran. Hasil yang diperoleh dari hasil uji coba menunjukkan sebagai beerikut:

a. $94 \%$ anak, perhatiannya tertuju pada video hingga selesai

b. $100 \%$ anak serius menonton

c. $100 \%$ anak antusias mengikuti lagu yang ada di video

d. $94 \%$ anak mengikuti alur cerita

e. $94 \%$ anak menyukai cerita dan lagu yang ada di video

Dari hasil uji coba maka didapatlah kesimpulan video ini efektif digunakan untuk menarik perhatian anak.

Untuk hasil ketercapaian tujuan pembelajaran

a. $70 \%$ anak dapat menyebutkan tempat ibadah yang ada di video, dan yang dapat disebut oleh semua anak hanya masjid mujahidin.

b. $35 \%$ anak dapat menyebutkan lokasi/alamat tempat ibadah

c. $88 \%$ anak tertarik untuk mengunjungi tempat ibadah tersebut

d. $65 \%$ anak dapat menghargai semua tempat ibadah

Dari hasil uji coba ini dapat dilihat bahwa tanpa bimbingan guru, anak
Vol 11, No 2 (2019)- Dian Miranda

masih belum mampu menunjukkan lokasi tempat ibadah dan juga belum mampu memahami harus menghargai semua tempat ibadah, namun jika dibantu dengan penjelasan guru semua anak dapat mengerti.

Beberapa masukan dari validator untuk mencapai tujuan pembelajaran:

Ditambahkan tulisan alamat tempat ibadah, intonasi diperlambat pada hal utama yang ingin disampaikan, terdapat kalimat yang jelas tentang tujuan misal "harus menghargai semua tempat ibadah"

4. Penyebaran

Penyebaran video yang telah dilakukan ialah menyerahkan file video ke TK

Al-Kausar

\section{Pembahasan}

Hasil uji kelayakan video animasi edukatif yang telah dilakukan menunjukkan bahwa video sangat layak digunakan sebagai media pembelajaran untuk mengembangkan karakter cinta tanah air, hal ini ditinjau melalui kriteria media pembelajaran video untuk anak, yaitu syarat ideal media pembelajaran video harus memenuhi beberapa kriteria antara lain kejelasan pesan, berdiri sendiri, akrab dengan anak, representasi isi, visualisasi/kualitas gambar baik, dapat digunakan klaiskal maupun individual (Riyana, 2007).

Video yang dirancang bertujuan untuk mengembangkan karakter cinta tanah air dalam hal ini anak peduli dan merasa bangga dengan lingkungan sekitar yaitu memilik bangunan macam-macam tempat ibadah yang dapat dibanggakan. Isi video memberikan pengetahuan lokasi tempat 
DOI: $\underline{10.26418 / \text { jvip.v11i2.32565 }}$

ibadah masjid mujahidin, gereja katedral, vihara maitreya, dan pura giri pati mulawarman yang ada dipontianak. Tujuannya agar anak tertarik untuk mengunjungi tempat-tempat tersebut, mengakui keindahan dan bangga dengan bangunan-bangunan tersebut, serta dapat menghargai bangunan-bangunan tersebut sebagai tempat ibadah masing-masing agama.

Hanya saja dari nilai yang diperoleh terdapat beberapa kekurangan dari media yang telah dikembangkan yaitu aspek kemandirian dan kualitias gambar. Hasil pengamatan ketika dilakukan refleksi setalah menonton video ini, anak masih belum mampu memahami harus menghargai semua tempat ibadah sebagai tempat ibadah masing-masing agama, namun jika dibantu dengan penjelasan guru semua anak dapat mengerti, selain itu dalam hal kualitas gambar tim validator merasa kurang puas dengan animasi yang hanya menggunakan teknologi $2 \mathrm{D}$, padahal saat ini animasi yang berkembang sudah 3D.

Respon anak ketika menonton video animasi dalam mengembangkan karakter cinta tanah air pada anak usia dini sudah memadai, hal ini terlihat ketika menonton video animasi yang telah dikembangkan ini semua anak di kelas serius tertuju pada video yang ditayangkan. Anak menyukai dan menonton hingga selesai dengan antusias. Sesuai dengan manfaat media pembelajaran menurut (Mustikasari, 2008), media pembelajaran bermanfaat untuk mengurangi terjadinya kesenjangan informasi pada setiap anak yang belajar karena mendapatkan kualitas dan kuantitas pegetahuan yang sama, dapat membantu guru untuk menciptakan suasana belajar menjadi lebih hidup, tidak monoton dan
Vol 11, No 2 (2019)- Dian Miranda

tidak membosankan, dapat memotivasi terjadinya komukasi dua arah secara aktif, Efisiensi dalam waktu dan tenaga, membantu anak menyerap materi belajar lebih mandalam dan utuh, membantu anak dapat melakukan kegiatan belajar dengan lebih leluasa dimanapun dan kapanpun tanpa tergantung kepada seorang guru, membuat Proses pembelajaran menjadi lebih menarik sehingga mendorong siswa untuk mencintai ilmu pengetahuan dan gemar mencari sendiri sumber-sumber ilmu pengetahuan, mampu mengubah peran guru ke arah yang lebih positif dan produktif. Dari respon yang dimunculkan anak ketika menonton video maka dapat disimpulkan media yang dikembangkan telah dapat memenuhi manfaat dari penggunaan media dalam pembelajaran.

Hal kemampuan media dalam menunjang ketercapian tujuan pembelajaran, menurut hasil pengamatan yang diperoleh ketika dilakukan diskusi mengenai video yang telah di tonton, ternyata masih sedikit anak yang mampu menyebutkan lokasi tempat ibadah yang ada di video, hal ini dikarenakan alamat merupakan inrformasi yang cukup komplek dan bersifat abstrak, sehingga akan sulit bagi anak usia dini untuk mengingatnya jika tidak diulang-ulang dan disampaikan dengan perlahan. Namun anak tau tempattempat ibadah tersebut terletak di Pontianak dan dapat mereka kunjungi. Serta belum banyak anak mampu menjawab bagaimana harus bersikap dengan pemeluk agam lain, oleh karena itu anak perlu untuk dibimbing guru dalam memahami video tersebut agar anak dapat memahami harus dapat menghargai tempat semua tempat ibadah masing-masing agama. 
DOI: $\underline{10.26418 / \text { jvip.v11i2.32565 }}$

Pengaruh televisi bagi anak-anak berbeda dengan pengaruh televisi bagi orang dewasa. Anak-anak juga belum dapat membedakan antara adegan yang bersifat khayalan dan adegan yang bersifat fakta dan benar-benar terjadi. Mereka menganggap bahwa apa yang mereka saksikan ditelevisi semuanya adalah realitas dan benar-banar terjadi. Sehingga mereka sering mencontoh perbuatan yang sama dan kadang-kadang sangat membahayakan diri serta jiwa mereka, dan televisi merupakan media yang paling mudah untuk mengajarkan perilaku buruk bagi anak-anak. (Gunarsa , 2000). Komisi Perlindungan Anak Indonesia (KPAI) mengatakan bahwa 20-30\% tayangan televisi terutama film kartun sangat mempengaruhi perkembangan perilaku anak dalam hal yang negative (KPAI , 2008). Sedangkan hasil penelitian Bavelier (2008) Children, Wired: For Better and for Worse menyimpulkan bahwa kemajuan teknologi menjadikan semakin mudahnya hiburan seperti televisi, video ataupun game berdampak pada perilaku anak. Anak yang sering melihat tayangan televisi secara terus menerus tanpa adanya pengawasan dari orang tua menjadikan perilaku anak menjadi buruk. Anak cenderung lebih kasar dan pemarah sebagai akibat meniru pola adegan dari tokoh kartun yang ada di televisi ataupun di permainan game tesebut. Oleh sebab itu bimbingan orangtua sangat penting dalam mendampingi anak ketika menonton televisi agar pengetahuan dan informasi yang diterima anak dapat terkontrol sehingga sikap dan perilaku anak tetap sesuai dengan nilai dan norma yang berlaku di masyarakat. Bimbingan orang tua sangat penting dalam membimbing anak-anak dalam menonon film kartun
Vol 11, No 2 (2019)- Dian Miranda

yang dapat merugikan pribadi anak (Situmorang, 2016). Oleh sebab itu, sebaik apapun film yang dikonsumsi anak, tetap harus dibimbing oleh orang tua agar anak dapat mendapat manfaat dengan maksimal dari tontonan yang mereka tonton.

\section{SIMPULAN DAN SARAN Kesimpulan}

Hasil penelitian menunjukkan bahwa video berbasis karakter cinta tanah air yang telah dikembangkan oleh peneliti masuk dalam kategori sangat layak, dan hasil ujicoba lapangan menunjukkan video animasi yang dikembangan telah mampu menarik perhatian anak membuat anak serius dan menyenangi proses pembelajaran, serta mampu mencapai tujuan pembelajaran yaitu membuat anak mengetahui ada beberapa agama dengan masing-masing tempat ibadahnya selain agama yang dianutnya, memperlihatkan kehidupan yang rukun antara anak yang berbeda agama dan berbeda suku dan peredaan tampilan fisik, berupa warna kulit, rambut, dan logat yang digunakan setiap tokoh yang ada dalam film animasi, namun demikian untuk memastikan anak mampu memahami untuk hidup rukun dengan sesama walau memiliki berbagai perbedan diperlukan arahan dan bimbingan guru.

\section{Saran}

Peneliti selanjutnya dapat mengembangkan video serupa dengan teknologi lebih baik misalnya 3D, atau menambah konten cinta tanah air yang lebih banyak atau yang belum dikembangkan dalam video ini. 
DOI: $\underline{10.26418 / j v i p . v 11 i 2.32565}$

\section{DAFTAR RUJUKAN}

Atika, S. (2014). Pelaksanaan pendidikan karakter (religius, cinta tanah air dan disiplin) di SLB Al Ishlaah Padang. Padang: E-Jupekhu. 3 (3), 750-751.

Bavelier D., Shawn Green, and Matthew W.G.Dye. 2008. Children, Wired : For Better and For Worse. Jpournal Neuron 67, September 9, 2008 Elsevier Inc.

Erni, M. (2016). Internalisasi Nilai-Nilai Pancasila dan Rasa Cinta Tanah Air pada Remaja di Perbatasan Indonesia-Malaysia.

PSIKOBORNEO, 4 (4), 849-856.

Gunarsa, S.D. 2000. Psikologi Perkembangan Anak Dan Remaja. Jakarta : Gunung Mulia

Haryatmoko. (2007). Etika komunikasi: Manipulasi media, kekerasan dan pornografi. Yogyakarta: Kanisius anggota IKAPI.

KPAI. 2008. Kartun Negatif. Di akses Tgl. 23 Januari 2012, Jam 20.00 dari : http://

blog.tp.ac.id/KOMPASKPAI//2008.c om.
Vol 11, No 2 (2019)- Dian Miranda

Kusumadana, Reni. 2016. Pengaruh Penggunaan Media Video Terhadap Kecerdasan Emosional Anak Kelompok A Di Taman KanakKanak. Jurnal Pendidikan Guru Pendidikan Anak Usia Dini Edisi 4 Tahun ke-5. Hal. 419-429.

Mustikasari, A. (2008, September 9). MENGENAL MEDIA PEMBELAJARAN. Retrieved from MUHAMMAD FAJRI: https://vhajrie27.wordpress.com/20 08/09/09/mengenal-mediapembelajaran/

Rusyan, T;. (2013). Membangun disiplin karakter anak bangsa. Jakarta: PT Pustaka Dinamika.

Situmorang. J. 2016. pendamping orang tua dengan aktivitas Anak menonton Televisi http://download.portalgaruda.org) Disearch bulan october 2016

Zaini. 2010. Penguatan Pendidikan Toleransi Sejak Usia Dini (Menanamkan Nilai-nilai Toleransi Dalam Pluralisme Beragama Pada Pendidikan Anak Usia Dini (PAUD) Di Kabupaten Tulungagung Tahun 2010). Ejournal.uin.Toleransi Vol.2, No.1. 